\title{
Stakeholder Orientation for Social Value Creation: A Case Study
}

\author{
B.A.N. Eranda ${ }^{1 *}$, B.A.I.R. Sumanarathna ${ }^{2}$ \\ ${ }^{1}$ Department of Marketing Management, Faculty of Management, \\ University of Peradeniya, Peradeniya, Sri Lanka \\ ${ }^{2}$ Beta Company, Sri Lanka \\ *Corresponding author: nuresheranda@pdn.ac.lk
}

Received: August 17, 2019

Accepted: October 22, 2019

\section{ABSTRACT}

The integration between business and society is a priority in the current business world, and it is an emergent area of research in the extant literature. Business organizations are pursuing the interdependency between business and society using business ethics, corporate social responsibility, and shared value. Stakeholder orientation is the cornerstone of these new initiatives and it is growing in the future. Therefore, this paper intends to explain the nature of a stakeholder-oriented business organization with its contribution to social value creation. Based on interpretivism, researchers adopted a qualitative embedded single case study design methodology. The organization under study is a small scale manufacturing company in Kandy working with multiple stakeholders. Data was collected using secondary sources and by conducting in-depth interviews with the owner of the company, self-employed rural artisans and entrepreneurial suppliers who were selected using a judgmental sampling method. Data analysis involves transcription, summary and keyword development. The final stage of the analysis was conducted by cross-tab analysis and interview findings are even analyzed using discourse analysis. As per the analysis, the company has shown that a stakeholder-oriented business approach maintains a strong relationship with stakeholders by focusing on multiple stakeholder interests and deep stakeholder understanding. The company works collaboratively with rural artisans, 
private sector organizations and small scale entrepreneurial suppliers. The continuous stakeholder dialogue is a salient feature in this business approach. Social value creation of stakeholder orientation was evidenced through income enhancement, improvement in living conditions, citizenship enhancement and social capital development. Further, the feeling of engagement in work and supporting the education of the children also emerge in the data as social value creations. Researchers contend that it is important to uncover each stakeholder's unique social issues in social value creation and conclude that connectivity can be created between a business organization and social issues through stakeholder orientation.

Keywords: Stakeholder orientation, Social value, Business and society, and Case study method

\section{Introduction}

The interrelationship between business and society is a profound discussion in the current business world. More importantly, this has been an emergent area of research in the extant literature (Prahalad and Hammond, 2002; Prahalad, 2006; Porter and Kramer, 2002; 2006; 2011). Furthermore, new business initiatives are pursued to capitalize on this interdependency between business and society using business ethics and corporate social responsibility and recently through corporate shared value. Particularly, the sustainable competitive advantage in contemporary business organizations is heavily relied on how it deals with society and not with how capable the business is or how dynamic the industry it operates in. Business organizations have traditionally emphasized the shareholder value maximization, but currently, they are increasingly adopting sustainabilityoriented practices (Amran et al., 2013; Amran and Ooi, 2014). At this juncture, stakeholder orientation can be identified as a focal point to change the priorities of business organizations. Further, it has become the cornerstone of future management and the strategy of business organizations by connecting the business and society. As a consequence, the importance of stakeholder orientation will grow in the future where the business organizations have to enhance their investments to connect with society for enhancing competitiveness. 
Therefore, exploring the idea of stakeholder orientation is significant as a prominent approach to demystify the nature of modern business organizations for which the researchers intend to contribute.

\subsection{Research objectives}

This paper intends to uncover the notion of stakeholder orientation and its contribution to creating social value. Therefore, this paper answers the following research questions.

- What are the characteristics of a business organization oriented towards the stakeholders?

- How does such a business organization create social values?

\subsection{Research methodology}

This study is based on interpretivism, where the researchers directly deal with the informants to understand their insider perspective. Moreover, researchers aim at understanding and explaining the social reality through the eyes of different participants and the results are interpreted from words concerning a social setting. Therefore, this study adopted a qualitative embedded single-case design as the methodology of the study (Yin, 2009). The case study selected for this study is named Beta Company Private Limited for confidentiality reasons which are a small-scale company situated in Kandy in Sri Lanka. This company is selected due to the following criteria: (i) it defines itself as a company working with a network of stakeholders, (ii) it is recognized for its social performance and (iii) it sells and makes products using the talents of rural artisans. Data was collected for this study by referring to the secondary data sources including company website and relevant company documentary evidence. Further, eight in-depth interviews were conducted with key informants including the owner of the company, self-employed rural artisans and other entrepreneurs who are supplying products. The key respondents were selected based on judgmental sampling for the study (Saunders et al., 2012). Neuman (2006) also pointed out that judgmental sampling is often used when working with very small samples in case study research and selecting particularly 
informative cases. The approach to data analysis of this paper involves the stages of transcription, summary and keyword development. Therefore, firstly the audio recordings of the interviews are taken and transcribed. After that, the key findings are summarized from the transcripts based on thematic analysis. The thematic analysis is chosen since this research is concerned about commonalities or themes that appeared across key informants (Longbottom and Lawson, 2017). However, the researchers incorporate even the new emergent themes generated from field research conducted through in-depth interviews by adopting the abductive approach. The final stage of the analysis was conducted by constructing a cross-tab analysis where the key informants are compared against key themes and vice-versa to uncover the patterns of similarity and differences. In addition to that, interview findings are analyzed using a discourse analysis method that is capable of revealing phenomena that might be unavailable to traditional research methods. As Longbottom and Lawson (2017) contended, discourse analysis has enabled the researchers to uncover the respondents' inner insights and identify actions carried out.

\section{Literature review}

Stakeholder orientation has been subjected to scholarly inquiry across various organizations and industries. Freeman (1984) defined a stakeholder as 'any group or individual who can affect or is affected by the achievement of the firm's objectives' (Freeman, 1984, p. 49). Moreover, a comprehensive definition of stakeholder theory is provided by Clarkson (1995) as follows. 'The firm is a system of stakeholders operating within the larger system of the host society that provides the necessary legal and market infrastructure for the firm activities. The purpose of the firm is to create wealth or value for its stakeholders by converting their stakes into goods and services'. Therefore, the objective of the stakeholder theory is to create value for the organization's constituents. Particularly, it extends the shareholder model (i.e. earning profits) by incorporating the legitimate claims of all the stakeholders (Kakabadse et al., 2005). Accordingly, stakeholder theory can be considered as a balanced view to look at the organizational activities. 
Scholars provided classifications of stakeholders including internal and external stakeholders (Carroll, 1989); strategic and moral stakeholders (Goodpaster, 1991); latent, expectant and definitive stakeholders (Mitchell et al. 1997); single and multiple issue stakeholders (Wood, 1994) and primary and secondary stakeholders (Clarkson, 1995). Based on these categorizations, it is clear that there are stakeholders with different priorities in the organization. According to Carroll (1991), commonly identified stakeholders in an organization include shareholders, employees, customers, suppliers, local community, competitors, interest groups, government, media, and society at large. Lantos (2001) mentioned that stakeholders are explained as existing at four levels in an organization, as shown in figure 1.

Figure 1: Four Levels of Stakeholders

1. Systematic/macro environmental/general environment level - larger societal factors, entire business system, social system, society at large (institutions and forces)

2. Micro environmental/operating/task environment - immediate environment including exchange relationship partners (suppliers and distributors), competitors, customers, the local community, financial community (stockholders, bondholders, and creditors)

3. Internal stakeholders - superiors, subordinates, other employees, and labor unions

4. Business decision makers

Source: Lantos (2001, pp. 604-605)

Even there are many interpretations and classifications about stakeholder theory; two prominent approaches were emerged: instrumental and normative (ethical) approach. According to an instrumental approach, stakeholder theory is considered as a mechanism to achieve expected outcomes and which is mainly profits. Therefore, this approach is considered a primary perspective on stakeholder theory. However, Freeman (1984) and Jones and Wicks (1999) argued that there are normative, ethical elements to stakeholder theory beyond the instrumental approach. According to Evan and Freeman (1988), stakeholder theory focuses on 
managing the business for the benefit of its stakeholders: customers, suppliers, owners, employees, and local communities and to maintain the survival of the organization. The decision-making structure of the organization should incorporate the ideas of stakeholders. Hence, the normative approach considers the ethical legitimacy of the stakeholders.

Among these two approaches, the instrumental approach was more vulnerable to criticisms since it considers only the economic reasons for making strategic decisions in the organization (Kakabadse et al., 2005). Particularly, stakeholder theory becomes a real challenger for shareholder model because it's ethical (normative) dimension maintains that business organizations are not simple or only economic by nature, but they can behave in a socially responsible manner like other members in the society (Weiss, 2003, p. 30). Therefore, if business organizations want to guarantee their legitimacy in society, they should consider the interests and responsibilities of all the stakeholders. In other words, organizations are required to meet the multiple expectations of stakeholders rather than satisfying only the shareholders. The idea of the normative approach was advanced by Jones (1995) by describing that if firms contract with their stakeholders through developing mutual trust and cooperation, they will have a competitive advantage over firms that do not. Moreover, according to Sanford (2011), responsible businesses have to deal with their stakeholders through a deeper understanding of each stakeholder has in a better life for the end-user. Further, they need to have an enlarged definition of capital considering the investment made by each stakeholder. This should include not only the money but also the emotional component as well. This idea is similar to the argument behind 'convergent stakeholder theory' where the simultaneous achievement of morally sound behavior and instrumentally viable economic outcomes are critical (Jones and Wicks, 1999). Therefore, value creation emerged from stakeholder orientation is broader in scope which extends beyond the mere economic value generation for shareholders. Particularly, Post et al. (2002) developed the new stakeholder view of the firm which focused on the role of stakeholder relationships for creating organizational wealth. This approach is more 
suitable for analyzing the extended organizations which possess a network of stakeholders. Further, they highlighted that the long term survival and the success of a firm are determined by its ability to establish and maintain relationships within its entire network of stakeholders. Therefore, it is important to maintain dialogues with its stakeholders to achieve long-term sustainable growth for the organization. Thus, the researchers can emphasize that stakeholder orientation can create value for both the stakeholders and the organization alike based on the extant literature and this is depicted in figure 2.

Figure 2: Stakeholder Management: Elements and factors of influence

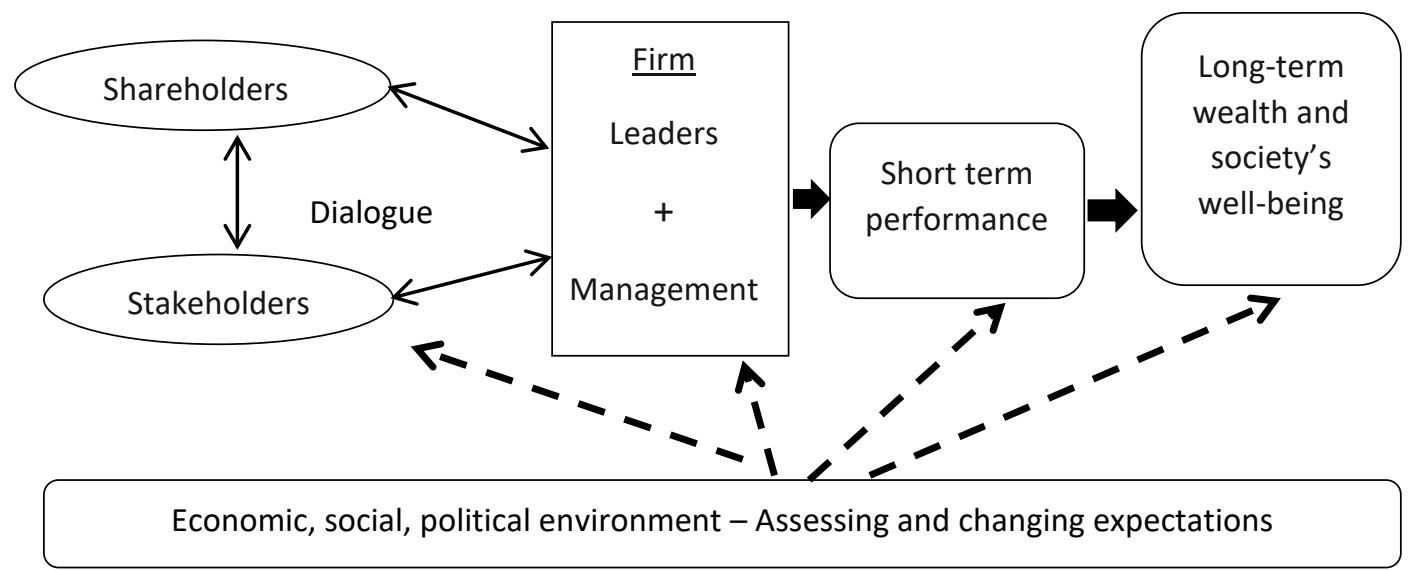

Source: Adapted from Kakabadse et al. (2005)

\subsection{Social value creation - Literature review}

The creation of social value has been increasingly considered as an obligation within the modern business ecosystem. Accordingly, Rispal and Bonler (2010, p.114) defined social values as the relationship and the contribution to society as a whole in broader terms. To conceptualize the social value, the study conducted by Portocarrero and Delgado (2010) is significant. Based on 33 case studies in Latin America and Spain, they explained the concept of social value produced by socially inclusive marketbased initiatives involving the low-income sector. Therefore, they defined the term social value as "the pursuit of societal betterment through the removal of barriers that hinder social inclusion, the assistance to those 
temporarily weakened or lacking a voice, and the mitigation of undesirable side effects of economic activity." Therefore, in creating social value, it is important to link the organizational activities with social issues. Particularly, Dees (2001, p. 5) mentioned that social value creation is majorly considered resolving social issues such as generating income for economically excluded people and delivering medical supplies to poverty-stricken areas. Moreover, Drayton (2002) also reiterated the same idea pointing out social value involves the resolution of social problems (e.g., reduction of poverty).

Emerson et al. (2000, p. 137) mentioned that "Social value is created when resources, inputs, processes or policies are combined to generate improvements in the lives of individuals or society as a whole." Particularly, most of the non-profit organizations justify their existence based on this ground. When quoting Gregory Dees as cited in Emerson et al. (2000, p. 137), "Social value is about inclusion and access. It is about respect and the openness of institutions. It is about history, knowledge, a sense of heritage and cultural identity. Its value is not reducible to economic or socioeconomic terms". This statement implies that the creation of social value empowers the community members. Therefore, this has more intrinsic value and which is difficult to quantify. Certo and Miller (2008, p. 267) contended that "social value has little to do with wealth creation but instead with the fulfillment of basic and long-standing needs such as providing food, water, shelter, education, and medical services to those members of society who are in need." Therefore, social value creation has to meet the needs of society. Particularly, McLean (2006) and Sullivan Mort et al. (2003) pointed out that social value is about the development of social wealth such as education and economic development. This indicates that the development requirements of society should be addressed in creating social value.

The elements of social value creation were clearly explained by Portocarrero and Delgado (2010).As depicted in figure 3, researchers strongly believe that the depth of social value creation is adequately uncovered in this categorization. 
Figure 3: Elements of social value creation

1. Increasing income and expanding life options resulting from inclusion as productive agents into market value chains

3. Building political, economic, and environmental citizenship through restoring rights and duties
2. Expanding access to goods and services that improve living conditions

4. Developing social capital through constructing networks and alliances

Source: Adapted from Portocarrero and Delgado (2010)

Each of these elements in social value creation can be explained as follows.

Increasing income and expanding life options resulting from inclusion as productive agents into market value chains: Rural community in developing countries mostly deviates from the main formal economic activities, and they should be integrated through value chains of organizations as suppliers. Thereafter, these local suppliers can enhance productivity through training and technical advice. Further, it eliminates the intermediaries in the value chain guaranteeing a higher price for the local suppliers. The inclusion aspect is mainly about a person's ability to use his or her competencies. Sen (2000) also pointed out that the main problem of poverty is the deprivation of human freedom. Further, he explained that fair conditions should be created for poor people to improve their quality of life and for income generation.

Expanding access to goods and services that improve living conditions: The market-based initiatives are helpful to increase private investment in equipment and infrastructure. Further, local communities can access the loan mechanisms and also eliminate barriers for education for improving the living conditions. 
Building political, economic, and environmental citizenship through restoring rights and duties: This is about recognition and exercise of basic rights in work and life, increasing the dignity of life, intermediation of excluded and poor groups. Further, this includes the promotion of good hygiene habits and rational consumption.

Developing social capital through constructing networks and alliances: This consists of networking, local relationships, building a sense of belonging to a certain community, enhancing trust, availability of own and third-party resources through interactions, self-esteem enhancement, connecting with new markets and customers, etc.

In the meantime, Porter and Kramer (2011) argued that the boundaries are blurred between non-profit and for-profit sectors in the creation of social values by different types of business organizations. Accordingly, social value creation can be a part of the core business operations in the organization, or it can be a part of the peripheral activity.

\section{Stakeholder oriented business approach at Beta Company}

Beta Company Private Limited is a small-scale company situated in Kandy in Sri Lanka, exporting a range of ethically-sourced newsprint giftware and lifestyle products manufactured from recycled and discarded newspapers. It has capitalized on the individuality of handcrafting of rural artisans by achieving efficiency with simple manufacturing processes. Beta Company delivers a wide range of truly unique attractive items from home decor to gifts, packaging, corporate solutions, and hospitality and retail products. They have an array of beautifully designed newspaper bowls, baskets, table mats, coasters packs and other home decorative items that are exported to developed country markets including Italy, UK, USA, Australia, Dubai, Germany, and the Netherlands. The unique business approach oriented towards the stakeholders has made them a differentiated organization among the rivals. 
This organization targets sustainable, conscious customers who have the intention to purchase ethically-sourced and ethically-manufactured wares and to share in the joy of connecting with rural artisans. Accordingly, the company adopts an eco-friendly production process and labor intensity which is ideally suited for capitalizing local unemployed talent ranging from unskilled to skilled rural artisans. Beta Company provides a creative space for self-employed home-based artisans including women and youth from rural areas in Sri Lanka to utilize their skills productively and efficiently. Beta Company has established over seven production villages in the rural outskirts of the Northwestern, Central and Southern provinces of Sri Lanka in an attempt to move away from a traditional 'headquarter-based workshop model' to one which artisans can reach within the comfort of their own homes. In this way, the company has the steps not only to empower the rural artisans financially but also to create a way of life within which they are comfortable. Accordingly, table 1 presents extracts of the owner of Beta Company and a rural artisan worded regarding the relationships with respective stakeholders.

Table 1: Summary derived from a transcript

\section{Theme 1: Relationship with stakeholders}

"With the increasing market demand, I had to choose from either I start a factory and expand my production or else I involve with my village community and partner with them and train them to make these products. I selected the second option because I thought it is one of my social responsibilities that I cannot avoid."

Owner, Beta Company

"I am unable to visit the company to obtain the necessary materials. However, I have a close relationship with the company owner and also with their staff members. Therefore, whenever I need materials, they provide me with those to continue the weaving. So, I am very happy about this relationship, which makes me employed."

Rural artisan 1

Source: Compiled by the researchers based on interviews (2019) 
Table 2 presents the horizontal (thematic) analysis of the stakeholderoriented approach at Beta Company by showing the patterns of data based on the themes identified in line with the literature review.

Table 2: Summary analysis of stakeholder orientation using a cross-tabular method including thematic analysis

\begin{tabular}{|c|c|c|c|c|c|}
\hline \multirow[b]{2}{*}{ Themes } & \multicolumn{4}{|l|}{ Respondents } & \multirow{2}{*}{$\begin{array}{l}\text { Key } \\
\text { outcome } \\
\text { by theme }\end{array}$} \\
\hline & $\begin{array}{l}\text { Rural artisan } \\
2\end{array}$ & $\begin{array}{l}\text { Rural } \\
\text { artisan } 1\end{array}$ & Rural artisan 3 & $\begin{array}{l}\text { Rural artisan } \\
4\end{array}$ & \\
\hline $\begin{array}{l}\text { Consider the } \\
\text { interest of } \\
\text { stakeholder } \\
\mathrm{s}\end{array}$ & $\begin{array}{l}\text { Cannot go } \\
\text { outside for } \\
\text { work } \\
\text { because the } \\
\text { children are } \\
\text { at early ages } \\
\text { but need to } \\
\text { earn money }\end{array}$ & $\begin{array}{l}\text { Illness has } \\
\text { limited me } \\
\text { to home but } \\
\text { needs the } \\
\text { feeling of } \\
\text { engagemen } \\
\text { t with work }\end{array}$ & $\begin{array}{l}\text { Need to earn } \\
\text { money while } \\
\text { undertaking } \\
\text { the } \\
\text { responsibilitie } \\
\mathrm{s} \text { as a } \\
\text { housewife }\end{array}$ & $\begin{array}{l}\text { Need an } \\
\text { income source } \\
\text { closer to the } \\
\text { home because } \\
\text { going far away } \\
\text { is expensive } \\
\text { and time- } \\
\text { consuming }\end{array}$ & $\begin{array}{l}\text { Multiple } \\
\text { stakehold } \\
\text { er } \\
\text { interests }\end{array}$ \\
\hline $\begin{array}{l}\text { Understand } \\
\text { the needs of } \\
\text { stakeholder } \\
\text { s }\end{array}$ & $\begin{array}{l}\text { The feeling } \\
\text { of } \\
\text { economicall } \\
\text { y engaged }\end{array}$ & $\begin{array}{l}\text { Avoid the } \\
\text { loneliness } \\
\text { of being at } \\
\text { home }\end{array}$ & $\begin{array}{l}\text { Need to have } \\
\text { dignity while } \\
\text { earning }\end{array}$ & $\begin{array}{l}\text { Need to work } \\
\text { long hours } \\
\text { being closer } \\
\text { to the home }\end{array}$ & $\begin{array}{l}\text { Deep } \\
\text { stakehold } \\
\text { er } \\
\text { understan } \\
\text { ding }\end{array}$ \\
\hline
\end{tabular}

Source: Compiled by the researchers based on interviews (2019)

This analysis depicted in table 2 has enabled to uncover two key outcomes by theme, including multiple stakeholder interests and deep stakeholder understanding. The emergent theme of 'multiple stakeholder interests' is an essential element in the normative (ethical) approach to stakeholder theory (Freeman 1984 and Jones and Wicks 1999). In addition to that, this is important for Beta Company to guarantee its legitimacy in society to be an ethical organization. Further, as per Post et al. (2002), this organization has shown the characteristics of an extended organization by characterizing the multiple stakeholder interests. Moreover, Beta Company is closely working with private and plural sector organizations in Sri Lanka. This was evident in the interview conducted with the owner of the company, as presented in excerpt 1 (Key sections italicized). 


\section{Excerpt 1: Working with a private sector company}

Owner: $\quad$ Our Company has a close relationship with one of the largest (Beta cosmetics manufacturing companies in Sri Lanka. They generate lots of industrial waste papers monthly. Those papers are hardly Company) recyclable. None of Sri Lankan paper recycling companies are willing to purchase that waste paper from them. So they do not have any option other than disposing of as garbage. But, we obtain those waste papers from them and make a recycled paper bag. Thereafter, we sell those bags, and mostly the same cosmetics company is also buying from us. These bags are also made by rural artisans.

As per excerpt 1, the owner of Beta Company has pointed out that there is a "close relationship with one of the largest cosmetics manufacturing companies," which is a private sector company to get their waste paper as the main material to produce eco-friendly bags. Moreover, "mostly the same cosmetics company is also buying" those eco-friendly bags from Beta Company. The other important phenomenon is these "bags are also made by rural artisans." Therefore, this has featured a business network; in other words, the nature of an extended organization explained by Post et al. (2002). More importantly, this extended organization has two notable features as reflected in excerpt 1. Firstly, it is based on environmental sustainability through reusing waste papers which "are hardly recyclable." Secondly, the manufacturing process of recycled paper bags is inclusive since it is done "through rural artisans."

The second emergent theme of 'deep stakeholder understanding' was highlighted by Sanford (2011) as a feature of responsible business. Particularly, researchers understood that this deep understanding of artisans made them more loyal to the Beta Company. For instance, Rural artisan 4 has reflected her loyalty by comparing her current job at Beta Company with her earlier workplace by highlighting how she has been benefitted. Researchers have witnessed that the company's deep understanding of its stakeholders has facilitated to build a strong social capital within the nearby community benefitting the organization (explained under table 3). 
In addition to the private sector, Beta Company is also working very closely with some small scale entrepreneurs to strengthen its stakeholder-oriented business approach. Excerpt 2 provides evidence for this situation (Key sections italicized). This extract is obtained from an interview conducted with the owner of Beta Company.

\section{Excerpt 2: Working with a small scale entrepreneur}

Owner: $\quad$ Our Company has a relationship with Alpha Creations, which has a (Beta) operations Company) social enterprise business model located in Gampola. They are undertaking on a small scale level by having 20-30 self-employed home-based rural women as producers of booklets, file dockets, and decorative items by using recycled papers and boards.

According to excerpt 2, it is clear that Beta Company "has a relationship with Alpha Creations," which is also a small scale organization started by a creative entrepreneur in Gampola. This collaboration has also benefitted "self-employed home-based rural women." This has also once-again justified the extended organization characteristics of Beta Company. To uncover the nature of this collaboration researchers interviewed the entrepreneurial founder of Alpha Creations and it is presented as excerpt 3 (Key sections italicized).

\section{Excerpt 3: Contribution to the small scale entrepreneur}

Owner: $\quad$ Beta Company was really helpful in developing my small business as well organized structured business organization. They provided (Alpha us huge support as the main buyer of our products. Moreover, Creations) they supplied the raw materials on an on-going basis to sustain our business while even sharing innovative product ideas which are very important for people like us. The owner of Beta Company has personally introduced me to the Jathika Shilpa Sabhawa and the Chamber of Commerce which has greatly contributed us to become who we are today and also I believe this will be important for our future growth. 
Beta Company contributed to this small scale entrepreneur in numerous ways, including buying the products, supplying raw materials, sharing innovative product ideas and also by introducing to relevant authorities for further development. In looking at this collaboration, it is clear that the notion of stakeholder management has contributed to stakeholders to enhance their short term performance. In addition to that, this entrepreneur has ensured his business will grow in the future since they are introduced to important authorities such as "Jathika Shilpa Sabhawa and the Chamber of commerce" by Beta Company. Therefore, a small scale entrepreneur's ability to create long-term wealth will also be improved while enhancing his long-term wealth, as explained by Kakabadse et al. (2005). Furthermore, excerpt 3 implies that Beta Company has deeply understood the requirements of this entrepreneur from the phrase, "which is very important for people like us." Therefore, the understanding of stakeholders' requirements can be cited as a notable characteristic of a stakeholder-oriented business organization.

Researchers witnessed another salient feature at Beta Company, which can be identified as a cornerstone for the stakeholder-oriented business approach, and that is the notion of undertaking continuous stakeholder dialogues. This was featured in the interview conducted with the owner of the company, as presented in excerpt 4 (Key sections italicized).

\section{Excerpt 4: Continuous stakeholder communication}

Owner: $\quad$ We always discuss with rural artisans to figure out how to ensure (Beta benefits for them. Especially when the artisans are not competent Company) enough, we provide guidance and training that help them to reach higher standards in the production.

Further, our company regularly inspects production villages to ensure the removal of unethical business practices like using child labor. 
As per excerpt 4, undertaking continuous stakeholder communication is a kind of frequent activity at Beta Company since the owner has declared that they "always discuss with rural artisans." Particularly, they "provide guidance and training" for these artisans to make their products marketoriented. Further, they "regularly inspect production villages" mainly for the "removal of unethical business practices." This has implied that rural communities may use "child labor" for weaving activities mainly because these rural artisans are poorer, and they need even their kids to be employed. However, continuous stakeholder communication is contributing to avoid such unethical practices which will be important for Beta Company to market its products on ethical grounds mainly for the global buyers. Therefore, stakeholder communication is playing a significant role in maintaining and promote responsible business practices of Beta Company.

\subsection{Social value creation at Beta Company}

Weaving is often a quiet craft. Self-employed rural artisans work from their homes and deliver the products made to the business so they can watch over their children while they sleep. In this way, the company expects not only to empower them financially but also to create a way of life within which they are comfortable. The unique stakeholder-based business model highlights the need for change in the rules and practices of conventional trade and shows how a successful business can also put people first. It is a tangible contribution to the fight against poverty and the economic crisis in Sri Lanka. Table 3 shows the analysis of social value creation from the stakeholder-oriented business approach using the cross-tabular method. 
Table 3 Summary analysis of social value creation using a cross-tabular method including thematic and case analysis

\begin{tabular}{|c|c|c|c|c|c|}
\hline \multirow[t]{2}{*}{ Themes } & \multicolumn{4}{|c|}{ Respondents } & \multirow{2}{*}{$\begin{array}{l}\text { Key outcome } \\
\text { by theme }\end{array}$} \\
\hline & $\begin{array}{l}\text { Rural artisan } \\
\mathbf{2}\end{array}$ & $\begin{array}{l}\text { Rural } \\
\text { artisan } 1 \\
\end{array}$ & $\begin{array}{l}\text { Rural artisan } \\
\mathbf{3}\end{array}$ & $\begin{array}{l}\text { Rural artisan } \\
4\end{array}$ & \\
\hline $\begin{array}{l}\text { Increasing } \\
\text { income and } \\
\text { expanding life } \\
\text { options } \\
\text { resulting from } \\
\text { the inclusion }\end{array}$ & $\begin{array}{l}\text { Increased } \\
\text { income } \\
\text { compared to } \\
\text { earlier self- } \\
\text { employment } \\
\text { opportunity }\end{array}$ & $\begin{array}{l}\text { Able to } \\
\text { earn } \\
\text { additional } \\
\text { income in } \\
\text { addition to } \\
\text { the pension }\end{array}$ & $\begin{array}{l}\text { Increased } \\
\text { income }\end{array}$ & $\begin{array}{l}\text { Increased } \\
\text { income } \\
\text { compared to } \\
\text { the earlier } \\
\text { job }\end{array}$ & $\begin{array}{l}\text { Income } \\
\text { enhancement }\end{array}$ \\
\hline $\begin{array}{l}\text { Expanding } \\
\text { access to } \\
\text { goods and } \\
\text { services that } \\
\text { improve living } \\
\text { conditions }\end{array}$ & $\begin{array}{l}\text { Eliminate } \\
\text { barriers to } \\
\text { kids' } \\
\text { education, } \\
\text { being at home } \\
\text { is comfortable }\end{array}$ & $\begin{array}{l}\text { Financial } \\
\text { support for } \\
\text { own } \\
\text { medical } \\
\text { expenses }\end{array}$ & $\begin{array}{l}\text { Eliminate } \\
\text { barriers to } \\
\text { kids' } \\
\text { education }\end{array}$ & $\begin{array}{l}\text { Used money } \\
\text { for daily } \\
\text { necessities at } \\
\text { home }\end{array}$ & $\begin{array}{l}\text { Living } \\
\text { conditions } \\
\text { improved }\end{array}$ \\
\hline $\begin{array}{l}\text { Building } \\
\text { political, } \\
\text { economic, and } \\
\text { environmental } \\
\text { citizenship } \\
\text { through } \\
\text { restoring } \\
\text { rights and } \\
\text { duties }\end{array}$ & $\begin{array}{l}\text { Enhanced } \\
\text { dignity for } \\
\text { being } \\
\text { employed and } \\
\text { increased } \\
\text { social } \\
\text { awareness }\end{array}$ & $\begin{array}{l}\text { Self- } \\
\text { satisfaction } \\
\text { for working } \\
\text { with illness, } \\
\text { feeling of } \\
\text { work } \\
\text { engagement }\end{array}$ & $\begin{array}{l}\text { Enhanced } \\
\text { dignity for } \\
\text { being } \\
\text { employed } \\
\text { and feeling } \\
\text { of } \\
\text { supporting } \\
\text { the family } \\
\text { economically }\end{array}$ & $\begin{array}{l}\text { Increased } \\
\text { visibility } \\
\text { among the } \\
\text { fellow } \\
\text { villagers }\end{array}$ & $\begin{array}{l}\text { Citizenship } \\
\text { enhancement }\end{array}$ \\
\hline $\begin{array}{l}\text { Developing } \\
\text { social capital } \\
\text { through } \\
\text { constructing } \\
\text { networks and } \\
\text { alliances }\end{array}$ & $\begin{array}{l}\text { Capability } \\
\text { strengthening, } \\
\text { self-esteem } \\
\text { enhancement }\end{array}$ & $\begin{array}{l}\text { Building a } \\
\text { sense of } \\
\text { belonging } \\
\text { to a } \\
\text { workforce, } \\
\text { able to } \\
\text { avoid the } \\
\text { loneliness } \\
\text { of being at } \\
\text { home due } \\
\text { to illness }\end{array}$ & $\begin{array}{l}\text { Networking } \\
\text { with others, } \\
\text { Feeling } \\
\text { happy about } \\
\text { a frequent } \\
\text { visit to the } \\
\text { factory to } \\
\text { get materials }\end{array}$ & $\begin{array}{l}\text { Social } \\
\text { networking, } \\
\text { cooperation } \\
\text { development, } \\
\text { trust, feeling } \\
\text { happy by } \\
\text { working with } \\
\text { others }\end{array}$ & $\begin{array}{l}\text { Social capital } \\
\text { improvement }\end{array}$ \\
\hline $\begin{array}{l}\text { Key outcome } \\
\text { by the } \\
\text { respondent }\end{array}$ & $\begin{array}{l}\text { Family } \\
\text { supporter }\end{array}$ & $\begin{array}{l}\text { Engaged } \\
\text { satisfier }\end{array}$ & $\begin{array}{l}\text { Family } \\
\text { support } \\
\text { networker }\end{array}$ & $\begin{array}{l}\text { Engaged } \\
\text { beneficiary }\end{array}$ & \\
\hline
\end{tabular}

Source: Compiled by the researchers based on interviews (2019) 
In table 3, horizontal (thematic) analysis enables patterns to be identified by each theme developed according to literature. Accordingly, under the theme of increasing income and expanding life options, there is an emerging consensus that the artisans can benefit from 'income enhancement.' Secondly, the 'living conditions improved' by working as makers for Beta Company. Thirdly, artisans felt that they are valuable citizens of the society under the emerging consensus of 'citizenship enhancement' which was in the absence or lowered concerning their earlier employments are concerned. Finally, almost all the respondents realized that they could enhance their social relationships and networks under the outcome theme of 'social capital improvement.' In addition to that, table 3 depicts the vertical analysis of social value creation by pointing out the individual perspectives of cases (respondents). Accordingly, Rural artisan 2 can focus on the well-being of her family members and therefore, she became a 'family supporter' by being an artisan for Beta Company. In contrast, Rural artisan 1 who is an old person with many illnesses, can be identified as an 'engaged satisfier' since he is even able to avoid loneliness by being at home. In the meantime, Rural artisan 3 becomes a little different from Rural artisan 2 by building up relationships with others while contributing to the family, and hence her key outcome is labeled as 'family support networker.' The final respondent, Rural artisan 4 who is the youngest among all artisans, was able to be fully engaged as an artisan for earnings, and therefore, she is more of an 'engaged beneficiary.'

Moreover, some newer emergent themes of social value creation were also evidenced in conducting interviews with rural artisans, and the following excerpts uncover those emergent themes (Key sections italicized).

\section{Excerpt 5: The feeling of engagement in work}

Rural artisan 1: This income is fully used for my medicine, including the transport fee to the hospital. By working like this, I can minimize the son's burden. I really enjoy working just because of this reason. But the major reason is that when I am engaged in the work, I forgot my illness by which I received a greater mental relief. So this weaving 
activity is a meditation for me and I strongly believe this work is medicine by itself for my mental illness.

Excerpt 5 reflects the feelings of a person who stayed at home due to illness. Being an artisan, he earns money and that is used to "minimize son's burden." This implies that Rural artisan 1 is fully dependent on his son for his survival and he believes that it not the right thing to do as a father. Thus, he is very much satisfied with his work as an artisan and this is reflected in his statement that, "I really enjoy working just because of this reason." However, the main reason for his satisfaction as an artisan can be identified under the utterance of "when I am engaged with the work I forgot my illness." Even he has the idea "weaving activity is a meditation for me." Therefore, the feeling of engagement in work can create higher selfsatisfaction for people like Rural artisan 1, which can be identified as a novel approach of social value creation. Therefore, as Sen (2000) explained this had shown evidence of generating fair conditions for work which has enabled Rural artisan 1 to improve his income.

\section{Excerpt 6: Supporting education}

Rural artisan 2: I normally estimate the monthly cost for the education of children at the beginning of each month, and I plan my weaving activities for that month accordingly. Further, I can help children's schoolwork while weaving the products which I am unable to do with another job like working in a garment factory.

Excerpt 6 emphasized that the "weaving activities" at Beta Company contributed to the "education of children" as major social value creation. Researchers have identified that Rural artisan 2 has a greater interest and hope for her kids' education. This is reiterated by her statement that "I plan my weaving activities for that month accordingly." Particularly, as a lowincome rural mother, this is the only hope that they have to overcome poverty. Further, she highlighted she can "help children's schoolwork while weaving," and this implies that the weaving activities can complement 
children's education. Moreover, she compared this opportunity with "working for a garment factory" by which she is quite sure that helping the kids' education cannot be realized. When looking at this artisan's idea, it implies that being with the children is important for their future success which is facilitated through being an artisan; if not kids may not pursue a good education which can hinder their future success. Therefore, the enhancement of parent's opportunities to support children's education can also be identified as major social value creation.

\section{Conclusions, managerial and policy implications}

The above findings and the analysis have shown that stakeholder-oriented business organizations maintain a strong relationship with their stakeholders by focusing on multiple stakeholder interests as well as deep stakeholder understanding. Accordingly, the case study concerned in this study work collaboratively with rural artisans, private sector organizations, and a small scale entrepreneur who also has a network of artisans as makers. Moreover, continuous stakeholder dialogue is also a salient feature in this business approach. Accordingly, the extended organization concept which is developed on the foundation of stakeholder orientation, is evidenced in the selected case study. More importantly, this has contributed to environmental sustainability and also to promotes inclusive growth by empowering the disadvantaged rural community. According to Beta Company, the stakeholder-oriented approach requires an innovative system of thinking. In other words, local entrepreneurs should be able to find out new collaborative opportunities with other organizations and entrepreneurs by understanding that their organizations as open systems. However, the local entrepreneurs are required to be exposed to outside their business territory and scope which cannot be solely realized by them. In other words, this extends the responsibility for the relevant government authorities as well as for trade associations like the National Chamber of Commerce. Particularly, these relevant and responsible authorities are required to initiate forums and discussions to promote the interdependency and complementarity of local entrepreneurs for which the existing stance is 
at its minimal. However, when looking at the Beta Company, the entrepreneur by him or herself should also be resilient to benefit from stakeholder orientation by networking with relevant, beneficial constituents. Accordingly, entrepreneurs should concern about maintaining a dynamic interaction with their stakeholders. A prerequisite for this notion to be initiated is the promotion of formal and informal education for entrepreneurs for which the national universities can make a reasonable contribution. Accordingly, national universities can also focus on starting new study programs for local entrepreneurial development and also university academics need to uncover the needs and potential of local entrepreneurs through collaborative research.

A notable feature uncovered concerning the rural artisans is that every individual's social issues and problems are different from each other. Therefore, any initiative aiming at benefitting them should not develop an aggregate solution that may not address the real issues of the people. Therefore, an in-depth study should be undertaken before beginning any of the initiatives targeting to find out the real problems encountered by the community. Thereafter, business organizations can think of how to contribute to solving those exact community problems by adapting their stakeholder-oriented business approach. Moreover, as pointed out in this study, continuous stakeholder dialogue is one of the effective strategies that can be used in this situation. In addition to that, continuous stakeholder dialogue will contribute to understanding the evolving nature of social issues in the community, for which a separate study can be conducted in the future. Therefore, it is very much clear that the 'one-sizefits-all' mechanism will not work in addressing social issues not only through a stakeholder-oriented business approach but also through any social development initiatives. Accordingly, adaptive strategies need to be crafted by undertaking a consultative approach where the community's inputs can be solicited to make a positive impact on the community. However, it is also important to note that what is important for society should not necessarily have to be bad for the organization. Therefore, researchers need to 
emphasize that there is a potential dilemma to be addressed in balancing the benefits of both the community and the business organization. This aspect also requires some further research to shed light on finding out creative solutions for the dilemma.

When looking at the existing economic status in Sri Lanka, the government, as well as the social sector institutions, have failed to solve numerous societal issues where the normative frameworks are eroded. Hettige (2013) has also pointed out that social sector planning requires as much emphasis as economic planning, which has been given the least priority in Sri Lanka. Therefore, policymakers should thoroughly understand that economic and social issues are inseparable in preparing the development agenda for the country. Moreover, providing solutions for social issues is important to achieve a higher development status for the country. Currently, Sri Lanka has undergone numerous social issues including poverty, unemployment, malnutrition, lack of health and education facilities, inaccessibility to skills development and aging population, etc. Therefore, based on this study, it is clear that connectivity can be created between business organizations' operations and social issues based on a stakeholder-oriented business approach. Accordingly, the policymakers in social sector institutions, corporate sector business owners, managers as well as small scale entrepreneurs should work collaboratively to realize this new approach to solve the social issues while achieving success for the business organizations. 


\section{References}

Amran, A., Mohd Zain, M., Sulaiman, M., Sarker, T. and Ooi, S.K. (2013).Empowering society for better CSR: the case of Malaysia.Kajian Malaysia, Vol. 31 No. 1, pp. 57-78.

Amran, A. and Ooi, S.K. (2014).Sustainability reporting: meeting stakeholder demands. Strategic Direction, Vol. 30 No. 7, pp. 38-41.

Carroll, A.B. (1989).Business and Society Ethics and Stakeholder Management, Cincinnati, $\mathrm{OH}$ : South-Western Publishing.

Carroll, A.B. (1991).The pyramid of corporate social responsibility: toward the moral management of organizational stakeholders. Business Horizons, Vol. 34 No. 4, pp. 39-48.

Certo, S. T., and Miller, T. (2008).Social entrepreneurship: key issues and concepts. Business Horizons, Vol. 51 No. 4, pp. 267-271.

Clarkson, M.B.E. (1995).A stakeholder framework for analyzing and evaluating corporate social performance.Academy of Management Review, Vol. 20 No. 1, pp. 92-117.

Dees. J.G. (2001).The Meaning of "Social Entrepreneurship", available at http://www.caseatduke.org/documents/dees_sedef.pdf, accessed on August 22, 2014.

Drayton, B. (2002).The citizen sector: becoming as entrepreneurial and competitive as business.California Management Review, Vol. 44 No. 3, pp. $120-132$.

Emerson, J. Wachowicz, J. and Chun, S. (2000).Social Return on Investment: Exploring Aspects of Value Creation in the Non-profit Sector.The Roberts Foundation, San Francisco.

Evan, W.M. and Freeman, R.E. (1988).A stakeholder theory of the modern corporation: Kantian capitalism in Beauchamp, T. and Bowie, N. (eds.), Ethical Theory and Business, Englewood Cliffs, NJ: Prentice Hall, pp. 75-93. 
Freeman, R.E. (1984).Strategic Management: A Stakeholder Approach.Pitman Publishers, Marshfield, MA.

Goodpaster, K.E. (1991).Business ethics and stakeholder analysis.Business Ethics Quarterly, Vol. 1 No. 1, pp. 53-73.

Hettige, S. (2013).Proliferation of social issues and human suffering, Daily Mirror, available at http://www.dailymirror.lk/35092/proliferation-of-social-issuesand-human-suffering, accessed on September 28, 2017.

Jones, T.M. (1995).Instrumental stakeholder theory: a synthesis of ethics and economics.Academy of Management Review, Vol. 20 No. 2, pp. 404-437.

Jones, T.M. and Wicks, A. (1999).Convergent stakeholder theory.Academy of Management Review, Vol. 24 No. 2, pp.206-221.

Kakabadse, N.K., Rozuel, C. and Lee-Davies, L. (2005).Corporate social responsibility and stakeholder approach: a conceptual view. Business Governance and Ethics, Vol. 1 No. 4, pp. 277-302.

Lantos, G.P. (2001).The boundaries of strategic corporate social responsibility. Journal of Consumer Marketing, Vol. 18 No. 7, pp. 595-632.

Longbottom, D. and Lawson, A. (2017).Alternative Market Research Methods: Market Sensing, Routledge, New York.

McLean, M. (2006).Social entrepreneurship: a critical review of the concept.Journal of World Business, Vol. 41 No. 1, pp. 56-65.

Mitchell, R.K. Agle, B.R. and Wood, D.J. (1997).Toward a theory of stakeholder identification and salience: defining the principles of who and what really counts. Academy of Management Review, Vol. 22 No. 4, pp. 853-886.

Neuman, W.L. (2006).Social Research Methods: Qualitative and Quantitative Approaches, $6^{\text {th }}$ Edition, Pearson, Boston.

Prahalad, C.K. and Hammond, A. (2002).Serving the world's poor profitably.Harvard Business Review, Vol. 80 No. 9, pp. 48-58. 
Prahalad, C.K. (2006).The Fortune at the Bottom of the Pyramid: Eradicating Poverty through Profits, Upper Saddle River, NJ: Wharton School Publishing.

Porter, M.E. and Kramer, M.R. (2002).The competitive advantage of corporate philanthropy.Harvard Business Review, Vol. 80 No. 12, pp. 56-69.

Porter, M.E. and Kramer, M.R. (2006).Strategy and society: the link between competitive advantage and corporate social responsibility.Harvard Business Review, Vol. 84 No. 12, pp. 78-92.

Porter, M.E. and Kramer, M.R. (2011).Creating shared value.Harvard Business Review, Vol. 89 No. 1/2, pp. 62-77.

Portocarrero, F. and Delgado, Á. J. (2010).Inclusive business and social value creation. In Márquez, P., Reficco, E. and Berger, G. (Eds.), Socially Inclusive Business: Engaging the Poor through Market Initiatives in Iberoamerica, Cambridge: Harvard University Press, pp. 261-293.

Post, J.E., Preston, L.E. and Sachs, S. (2002).Managing the extended enterprise: the new stakeholder view. California Management Review, Vol. 45 No. 1, pp. 628.

Rispal, H. H., and Bonler, J. (2010).Social entrepreneurship in France: organizational and relational issues.In Fayolle, A. and Matlay, H. (eds), Handbook of Research on Social Entrepreneurship, UK: Edward Elgar Publishing Ltd, pp. 109-124.

Sanford, C. (2011).The Responsible Business: Reimagining Sustainability and Success.Jossey-Bass, San Francisco, CA.

Saunders, M., Lewis, P. and Thornhill, A. (2012).Research Methods for Business Students, Pearson Education Ltd., Harlow.

Sen, A. K. (2000). Social Exclusion: Concept, Application, and Scrutiny. Manila: Office of Environment and Social Development, Asian Development Bank. 
Sullivan Mort, G., Weerawardena, J., and Carnegie, K. (2003).Social entrepreneurship: towards conceptualization.International Journal of Nonprofit and Voluntary Sector Marketing, Vol. 8 No. 1, pp. 76-88.

Weiss, J.W. (2003).Business Ethics: A Stakeholder and Issues Management Approach, South-Western, Thomson Learning, Mason.

Wood, D.C. (1994).Business and Society, New York, Harper Collins.

Yin, R.K. (2009).Case Study Research: Design and Methods, Sage Publications, Inc. 